\title{
Tenascin Knockout Mice: Barrels, Boundary Molecules, and Glial Scars
}

\author{
Dennis A. Steindler, ${ }^{1}$ Daniel Settles, ${ }^{2}$ Harold P. Erickson, ${ }^{2}$ Eric D. Laywell, ${ }^{1}$ Atsushi Yoshiki, ${ }^{3}$ Andreas \\ Faissner, ${ }^{4}$ and Moriaki Kusakabe ${ }^{3}$ \\ 'Department of Anatomy and Neurobiology, University of Tennessee, Memphis, Tennessee, ${ }^{2}$ Department of Cell \\ Biology, Duke University, Durham, North Carolina, ' 2 aboratory of Cell Biology, RIKEN, Tsukuba, Ibaraki, Japan, \\ and ${ }^{4}$ Department of Neurobiology, University of Heidelberg, Germany
}

In light of a previous report suggesting that the brains of tenascin-deficient animals are grossly normal, we have studied the somatosensory cortical barrel field and injured cerebral cortex in postnatal homozygous tenascin knockout, heterozygote, and normal wild-type mice. Nissl staining, cytochrome oxIdase, and Dil axonal tracing of thalamocortical axonal projections to the somatosensory cortex, all reveal the formation of normal barrels in the first postnatal week in homozygous knockout mice that cannot be distinguished from heterozygote or normal wild-type barrels. In addition to confirming the absence of tenascin in knockout animals, and reporting apparently reduced levels of the glycoprotein in barrel boundaries of heterozygote animals using well-characterized antibodies and immunocytochemistry, we also studied the DSD-1-PG proteoglycan, another developmentally regulated molecule known to be associated with transient glial/glycoconjugate boundaries that surround developing barrels; DSD-1-PG was also found to be expressed in barrel boundaries in apparently normal time frames in tenascin knockout mice. Peanut agglutinin (PNA) binding of galactosyl-containing glycoconjugates also revealed barrel boundaries in all three genotypes. We also examined the expression of tenascin-R, a paralog of tenascin- $C$ (referred to here simply as tenascin). As previously reported, tenascin- $R$ is prominently expressed in subcortical white matter, and we found it was not expressed in the barrel boundaries in any of the genotypes. Thus, the absence of tenascin does not result in a compensatory expression of tenascin- $R$ in the barrel boundaries. Finally, we studied wounds of the cerebral cortex in the late postnatal mouse. The astroglial scar formed, for the most part, in the same time course and spatial distribution in the wild-type and tenascin knockout mice. How-

\footnotetext{
Received July 14, 1994; revised Sept. 2, 1994; accepted Sept. 7, 1994.

We thank Donna Gates and Kristy Harrington for superb technical assistance, and Prof. Melitta Schachner for providing us with the pk7 polyclonal antibody to tenascin as well as the 619 and 620 monoclonal antibodies to tenascin-R. This work was supported by NIH Grant NS20856, NSF Grant IBN-9304203, and a grant from the Baptist Memorial Hospital Foundation (D.A.S., E.D.L.); NIH Grant R37CA47056 to H.P.E.; Grants SFB 317/A2 and Fa 159/5-1,2 to A.F. (A.F. is also a recipient of a Hermann- and Lilly-Schilling Stiftung Professorship); and Special Coordination Funds of the Scientific and Technology Agency of the Japanese Government (M.K.). This article is dedicated to the memory of Dr. William R. Mehler.

Correspondence should be addressed to Dennis A. Steindler, Ph.D., Department of Anatomy and Neurobiology, College of Medicine, University of Tennessee, 855 Monroe Avenue, Memphis, TN 38163.

Copyright (C) 1995 Society for Neuroscience $0270-6474 / 95 / 151971-13 \$ 05.00 / 0$
}

ever, there may be some differences in the extent of gliosis between the knockout and the wild type that warrant further study. Roles for boundary molecules like tenascin during brain pattern formation and injury are reconsidered in light of these findings on barrel development and cortical lesions in tenascin-deficient mice.

[Key words: tenascin-deficient mice, somatosensory cerebral cortex, cytochrome oxidase histochemistry, Dil axonal tracing, DSD-1-PG proteoglycan, tenascin-R, lectin cytochemistry, astrocytic scar]

Cell-cell interactions, mediated by unique recognition molecules (Faissner and Schachner, 1994), are believed to underlie the development of distinct cytoarchitectonic and connectional arrangements throughout the brain (for review, see Sanes, 1989; Bixby and Harris, 1991; Jacobson, 1991; Edelman, 1992; Edelman and Jones, 1992). The large extracellular matrix (ECM) protein tenascin (reviewed by Erickson and Bourdon, 1989) is one of these rccognition molccules (Faissner and Schachner, 1994), and it is prominently expressed in different areas of developing, adult, and injured brain (Crossin et al., 1986; Laywell and Steindler, 1991; Bartsch et al., 1992; Laywell et al., 1992; Rettig et al., 1992; Brodkey et al., 1993, 1994). Tenascin is especially dense in some specific zones, where its concentration is estimated to be $1-2 \mathrm{mg} / \mathrm{ml}$, making it among the most abundant extracellular matrix proteins of the brain (Lightner et al., 1990). One of the most spectacular and precise localizations of tenascin is in the vibrissae-related barrel field of the developing somatosensory cortex (Steindler et al., 1989a; Crossin et al., 1990). The somatosensory cerebral cortex of rodents contains distinct aggregates of stellate neurons in layer IV that are aligned in a pattern that mirrors the arrangement of facial vibrissae (e.g., five rows of neuronal "barrels" that represent five rows of facial whiskers (Woolsey and van der Loos, 1970; Woolsey, 1990). The findings of glial and glycoconjugate boundaries around developing whisker barrels in the somatosensory cortex of mice suggested that these elements may be involved in the formation and/or stabilization of these unique cytoarchitectonic units. Using lectins that bind a variety of glycoproteins, glycolipids, and glycosaminoglycans, and immunocytochemistry for glial fibrillary acidic protein (GFAP), it was determined that radial glia, young astrocytes, and unidentified glycoconjugates cordon off emerging barrel patterns during a plastic period in barrel pattern formation (Cooper and Steindler, 1986a,b, 1989; McCandlish et al., 1989; Crandall et al., 1990). In the developing barrel field, 
glial/glycoconjugate boundaries evolve into cell-sparse interbarrel septae in the adult.

A number of ECM molecules have been localized to these transient boundaries, including tenascin (Crossin et al., 1989, 1990; Steindler et al., 1989a,b, 1990; Steindler, 1993), a chondroitin sulfate proteoglycan possibly expressed by neurons (cytotactin binding protein) (Crossin et al., 1989, 1990), and another chondroitin sulfate protenglycan (termed the 473 or DSD-1-PG proteoglycan (Faissner et al., 1988, 1994; Steindler et al., 1990). Just as remarkable as the spatial localization of the barrel field boundaries is their temporal pattern. The boundaries, as visualized by staining for proteins like tenascin, DSD-1-PG, or the less specific lectin stains, begin to appear between postnatal days 2 and 7 (P2-P7) (Cooper and Steindler, 1986a, 1989; O'Brien et al., 1987; McCandlish et al., 1989; Steindler et al., 1989a,b, 1990; Woolsey, 1990), correlating with the ingrowth of axons from the vibrissae-related barreloids of the thalamic ventrobasal complex (O'Leary, 1989; Jhaveri et al., 1991; Schlaggar and O'Leary, 1991; O'leary et al., 1992, 1994), and they disappear by the second to third postnatal weeks, correlating with the completion of synaptogenesis and functional barrel organization.

A unique opportunity to investigate the biological functions of tenascin was provided by the creation of mice lacking tenascin, produced by gene knockout techniques (Saga et al., 1992). It was truly surprising that the initial examination of these mice revealed no phenotypic difference in the gross organization or histology of the tissues of highest tenascin expression, in particular brain, lung, and thymus. The three favored explanations for the absence of phenotype are (a) that the function(s) of tenascin are subtle rather than essential for development, (b) that the functions of tenascin are limited to a subset of the tissues where it is expressed, and it is superfluous in some of the tissues of highest expression, and (c) that its functions are duplicated by other proteins coexpressed in the same tissues. The first two possibilities have been discussed in detail by Erickson (Erickson, 1993; also see Dickinson, 1988, for a warning that proteins may not have a functional role in every tissue where they are expressed). The third possibility could involve any protein, but usually focuses on related, paralogous proteins. Tenascins are now known to comprise a family, including tenascin-C (referred to here simply as tenascin), the original family member and the protein investigated here, tenascin- $R$ [possibly the mouse homolog to chicken restrictin, hence, tenascin-R (Rathjen et al., 1991; Erickson, 1993), previously referred to as tenascin $160 /$ 180, or janusin (Pesheva et al., 1989; Morganti et al., 1990)], and tenascin-X (reviewed in Erickson, 1993). There is, however, little overlap in the patterns of expression, as tenascin- $X$ is primarily expressed in muscle (Matsumoto et al., 1992) and tenascin- $\mathrm{R}$ may be restricted primarily to white matter of the developing and adult central nervous system (Fuss et al., 1993).

A potentially fruitful approach to discover functions of tenascin is to examine specific tissues in tenascin knockout mice in detail for defects in histology or arrangement of other proteins. The barrel field boundaries provide a point of study with two focused questions: (1) do the other ECM molecules still form normal boundaries in the absence of tenascin, one of the most prominent proteins in these boundaries, and (2) does the absence of tenascin affect the postulated role of these boundaries in restraining dendritic processes to a single barrel. Since previous studies also have correlated an enhanced expression of tenascin with a subset of astrocytes around brain wounds in the adult cortices (Laywell and Steindler, 1991; McKeon et al., 1991; Lay- well et al., 1992; Brodkey et al., 1994), we have extended this study to the potentially related question of the formation of astroglial scars (Clemente, 1958; Bignami and Dahl, 1976; Reier et al., 1983; Reier and Houle, 1988) in cortical wounds in wild type and tenascin knockout mice.

\section{Materials and Methods}

Animals. These studies were carried out on $\mathrm{TN}^{-} / \mathrm{TN}^{-}$homozygote, $\mathrm{TN}^{+} / \mathrm{TN}^{-}$heterozygote, and $\mathrm{TN}^{+} /^{+}$normal wild-type mice (total 32 , age postnatal day 5-13, P5-13, with the day of birth designated as P0). Tenascin knockout mice, originally produced by replacing the tenascin gene with the lacZ gene using homologous recombination in mouse embryonic stem cells (Saga et al., 1992), were back-crossed with the inbred strain GRS/A for seven generations. The mice were originally maintained under SPF conditions in the animal facility of Tsukuba Life Science Center, Riken, Tsukuba, Japan. Heterozygote $\mathrm{TN}^{+} / \mathrm{TN}^{-}$mice were selected by PCR analysis of tail samples and were crossed to produce the homozygous knockouts $\mathrm{TN}^{-} / \mathrm{TN}^{-}$. Additional tenascin knockout mice were produced by mating these homozygotes. The animals were anesthetized with ether or injections of sodium pentobarbital and perfused through the left ventricle with $4 \%$ paraformaldehyde in $0.1 \mathrm{M}$ phosphate buffered saline $(\mathrm{pH} 7.4)$. Following a $2-3 \mathrm{hr}$ postfixation in cold perfusate, the brains were stored in cold phosphate buffer before sectioning on a vibratome at $40 \mu \mathrm{m}$ in the tangential or parasagittal plane. For studies of barrel cortex, hemispheres were flattened between two glass slides before sectioning as flattened tangential sections (Woolsey and van der Loos, 1970; Cooper and Steindler, 1986a; Steindler et al., 1989a; Senft and Woolsey, 1991). Findings are also presented from lesion studies where a needle wound was made in the right cerebral cortex of P5 and P10 knockout and wild-type mice, with a $3 \mathrm{~d}$ survival. Sections from all of these brains were processed for cresyl violet staining, cytochemistry, immunocytochemistry, or DiI labeling, as described below. In order to facilitate comparisons of the various markers in brains from all three genotypes, at the same time maintaining quality control such that each of the markers could be evaluated within as well as across genotypes, hrains were hisected and left or right hemispheres were serially sectioned and reacted for either a single marker, or adjacent sections from a single hemisphere were reacted with up to four markers from those described below. For example, all sections from a single "flattened" hemisphere may be reacted for cytochrome oxidase, while parasagittal sections from the other hemisphere would be reacled for DSD-1-PG, peanut agglutinin, tenascin-R, and so on.

Cytochrome oxidase histochemistry. Vibratome sections were processed for cytochrome oxidase (CO) histochemistry (a putative neuronal activity marker) using the detailed protocol developed by Wong-Riley (Wong-Riley, 1979). In short, sections are incubated in a solution containing diaminobenzidine, cytochrome $c$, and sucrose in $0.05 \mathrm{M}$ phosphate buffer. This reaction yields a histochemical reaction product, associated with mitochondria in neurites (Carroll and Wong-Riley, 1984), that has been well described in previous studies of barrel synaptic neuropil.

Dil axonal tracing. Axonal tracing was performed in fixed brains (as previously described) (Godement et al., 1987; Senft and Woolsey, 1991) using the lipophilic tracer 1,1'-dioctadecyl-3,3,3',3'-tetramethylindocarbocyanine perchlorale (DiI, as described by Honig and Hume, Molecular Probes) (Honig and Hume, 1986). Brains postfixed in paraformaldehyde for 1-3 weeks were blocked at the midbrain-diencephalic junction, and crystals of the tracer were picked up on a needle or micropipette and inserted in the vicinity of the ventrobasal complex. The brains were incubated in fixative, in the dark, at $37^{\circ} \mathrm{C}$ for 3 weeks. They were then lightly flattened and sectioned at $150 \mu \mathrm{m}$ in the tangential plane, mounted in Aquamount, and examined and photographed on a fluorescence microscope through the rhodamine filter

Immunocytochemistry for tenascin, the DSD-1-PG proteoglycan (another boundary molecule), and the tenascin- $R$ glycoprotein. Sections from knockout, heterozygote, and wild-type mice were processed for immunocytochemistry using well-characterized mono- and polyclonal antibodies to tenascin and tenascin fusion proteins as previously described (Faissner et al., 1988; Steindler el al., 1989a, 1990; Faissner and Kruse, 1990; Bartsch et al., 1992). The data presented here on tenascin or the lack of tenascin expression in the knockout brain was obtained using a rabbit polyclonal antibody specific for mouse tenascin, made against a fusion protein between most of the fibronectin III repeats 
plus half of the fibrinogen domain of mouse tenascin and glutathion-Stransterase, that in Western blots only binds to tenascin (U. Dorries, personal communication). This antibody labels barrel boundaries in the developing brain in a manner that is extremely similar to that obtained using previously described polyclonal and monoclonal antibodies to tenascin (pJ1/tn, J1/TN2) (Faissner et al., 1988; Steindler et al., 1989a; Faissner and Kruse, 1990; Lochter et al., 1991; Bartsch et al., 1992; Faissner and Schachner, 1994). We also used fusion protein antibodies that recognize different epitopes of the tenascin molecule (generated by H. P. Erickson, unpublished observations).

Monoclonal antibody $473 \mathrm{HD}$ recognizes a membrane-associated, putative glial-derived extracellular matrix molecule termed DSD-1-PG (Faissner et al., 1994). DSD-1-PG is a chondroitin sulfate proteoglycan, and the mAb 473HD recognizes a hybrid glycosaminoglycan epitope in the proteoglycan (the DSD-1 sugar epitope) which consists of chondroitin sulfate-C and chondivitin sulfate-B (dematan sulfate). Tenascin-R was detected within monoclonal antibodies 619 and 620 , which are described in previous reports (Morganti et al., 1990). Sections were reacted overnight with the primary antibodies, and following 2-3 hr incubations in fluorescent-labeled secondary antibodies (for tenascin and tenascin-R, FITC-labeled anti-IgG, and for DSD-1, rhodamine-labeled anti-IgM) they were examined for immunofluorescence. The sections were examined and photographed on a Leitz fluorescence microscope. All sections processed for immunofluorescence were eventually counterstained with cresyl violet for Nissl analysis of cellular distributions within the somatosensory cortex (i.e., to verify the existence of cellular barrels).

Lectin cytochemistry. Lectin cytochemistry was performed also as previously described (Cooper and Steindler, 1986a; Steindler and Coopcr, 1987; Steindler et al., 1988), using biotinylated peanut agglutinin (PNA, arachis hypogea, Vector Laboratories) which preferentially bind to galactosyl $\beta-1,3$ linked $N$-acetylgalactosamine and galactose residues of glycoconjugates. Following overnight incubations (at $4^{\circ} \mathrm{C}$ ) of the lectin in Tris-buffered saline $(0.5 \mathrm{mg} / \mathrm{ml})$, the sections were then incubated for $2-3 \mathrm{hr}$ in avidin-FITC or avidin-AMCA before being examined under the fluorescence microscope.

Labeling of the astroglial scar. Following needle stab lesions of the right cerebral cortex of P5 and P10 knockout and wild-type mice, and a survival time of $3 \mathrm{~d}$, the fixed brains were processed for DSD-1-PG immunolabeling as described above, and also for glial fibrillary acidic protein (GFAP) immunocytochemistry using monoclonal or polyclonal antibodies (Lipshaw, Chemicon) as in our previous studies (Cooper and Steindler, 1986b, 1989; O'Brien et al., 1987; Steindler and Cooper, 1987; Steindler et al., 1990; Laywell and Steindler, 1991; Laywell et al., 1992). Some sections from the P13 cases were also processed for double labeling using antibodies to both GFAP and GAP43.

\section{Results}

Nissl staining of barrels in knockout versus normal animals

The whisker barrel field, which resides in layer IV of the rodent somatosensory cerebral cortex, is seen to best advantage in flattened and tangentially sectioned hemispheres (Woolsey and van der Loos, 1970). This approach was used in Figures 1-4. Figure $1, A$ and $B$, shows barrels in tenascin knockout and normal wildtype mice using Nissl staining. All aspects of cellular barrel composition appear to be normal in tenascin knockout mice, including the emergence of distinct, individual barrels in the first to second postnatal weeks, resulting from an increase in the number of barrel neurons within "walls" or "sides," a decrease in the number of cells in the barrel "hollows," and the emanation of cell-sparse "interbarrel septae." Figure 1, $A$ and $B$, documents Nissl-stained barrels of the smaller anterolateral whisker barrels from the P7 knockout and normal barrel cortex, with the above-listed features defining normal cytoarchitectonic barrels in both fields and in both phenotypes (despite some difference in contrast between these figures due to a slight difference in Nissl staining intensity).

DiI axonal tracing and cytochrome oxidase (CO) histochemistry

As in the casc of Nissl-stained barrels, Dil axonal tracing and $\mathrm{CO}$ staining both reveal attributes of barrel-like organization similarly in all three genotypes. It is well known that thalamocortical axonal projections, along with several brainstem projections to the somatosensory cortical barrel field, are topographically organized in barrel-like configurations [e.g., ventrobasal thalamic projections (Dawson and Killackey, 1985); raphe-cortical projections (Rhoades et al., 1990)]. Previous studies using DiI labeling of axons and their terminal fields (Jhaveri et al., 1991; Senft and Woolsey, 1991; Zhang and Cooper, submitted for publication), an axonal tracing method that exploits the transport of this lipophilic tracer along axons in fixed material, have shown that thalamocortical projections to the barrel cortex become refined in the first postnatal week, preceding the appearance of cellular barrels and glial/glycoconjugate boundaries (Cooper and Steindler, 1986a,b; Steindler et al., 1989a,b, 1990) (and see below). DiI axonal tracing of thalamocortical afferents in tenascin-deficient animals also reveals barrel patterns in the first postnatal week (Fig. $1 C$ ). Following the placement of Dil crystals that impinged upon the ventrobasal complex in knockout or normal animals, the patterns of labeled thalamocortical projections to the somatosensory cortex seemed identical. Barrel hollows exhibited densely labeled axonal arbors that defined individual barrels, and the extent of labeling between barrels (e.g., within interbarrel septae) seemed to diminish with postnatal age. As shown in Figure $1 C$, the P5 barrel field reveals individual barrels as well as clear-cut rows (comparable to that seen in the normal P5 barrel cortex, e.g., see Senft and Woolsey, 1991), indicating an apparently normal maturation of thalamocortical innervation from the medial division of the thalamic ventrobasal complex in tenascin knockout animals. These findings suggest that afferent axons still observe the barrel plan despite the absence of tenascin in harrel boundaries.

CO-stained, synaptic neuropil in barrel hollows is one of the most distinct and reliable markers of barrels, and Figure $1 D-G$ shows dense labeling in clear-cut individual barrels within rows representing posteromedial and anterolateral fields in P7 normal (Fig. $1 D, E$ ) and knockout (Fig. $1 F, G$ ) mice. Using this method, barrel sides and septae are lightly or negatively stained, highlighting the dense staining of barrel hollows, with no noticeable difference in knockout versus normal barrels (e.g., compare Fig. $1 E, G)$. One might predict that if dendritic patterning was altered in the mutant, this might be reflected by less conspicuous $\mathrm{CO}$ staining of individual barrels (e.g., individual barrel staining may be less distinct or "muddied"), since this method has been described as particularly staining dendritic mitochondria compared to somata or axons (Carroll and Wong-Riley, 1984). The welldefined barrel $\mathrm{CO}$ staining in P7 homozygotes, heterozygotes, and normal wild-type mice (it should be noted that some P13 and adult knockouts were also analyzed, and barrels appeared to be normal though not photodocumented here) suggests that dendrites may be normally confined (Woolsey, 1990) to their prospective barrels in the knockout somatosensory cortical barrel field as in normal animals.

\section{Tenascin staining in knockout versus heterozygote and normal} barrel cortex

In normal animals, during the first postnatal week, well-characterized monoclonal and polyclonal antibodies to tenascin and tenascin-fusion proteins (Kruse et al., 1985; Faissner et al., 1988; Steindler et al., 1989a; Faissner and Kruse, 1990) all demonstrate barrel boundaries that reveal barrel rows and individual barrels in the posteromedial and anterolateral barrel subfields (Fig. 2A,B) as previously described (Steindler et al., 1989a, 

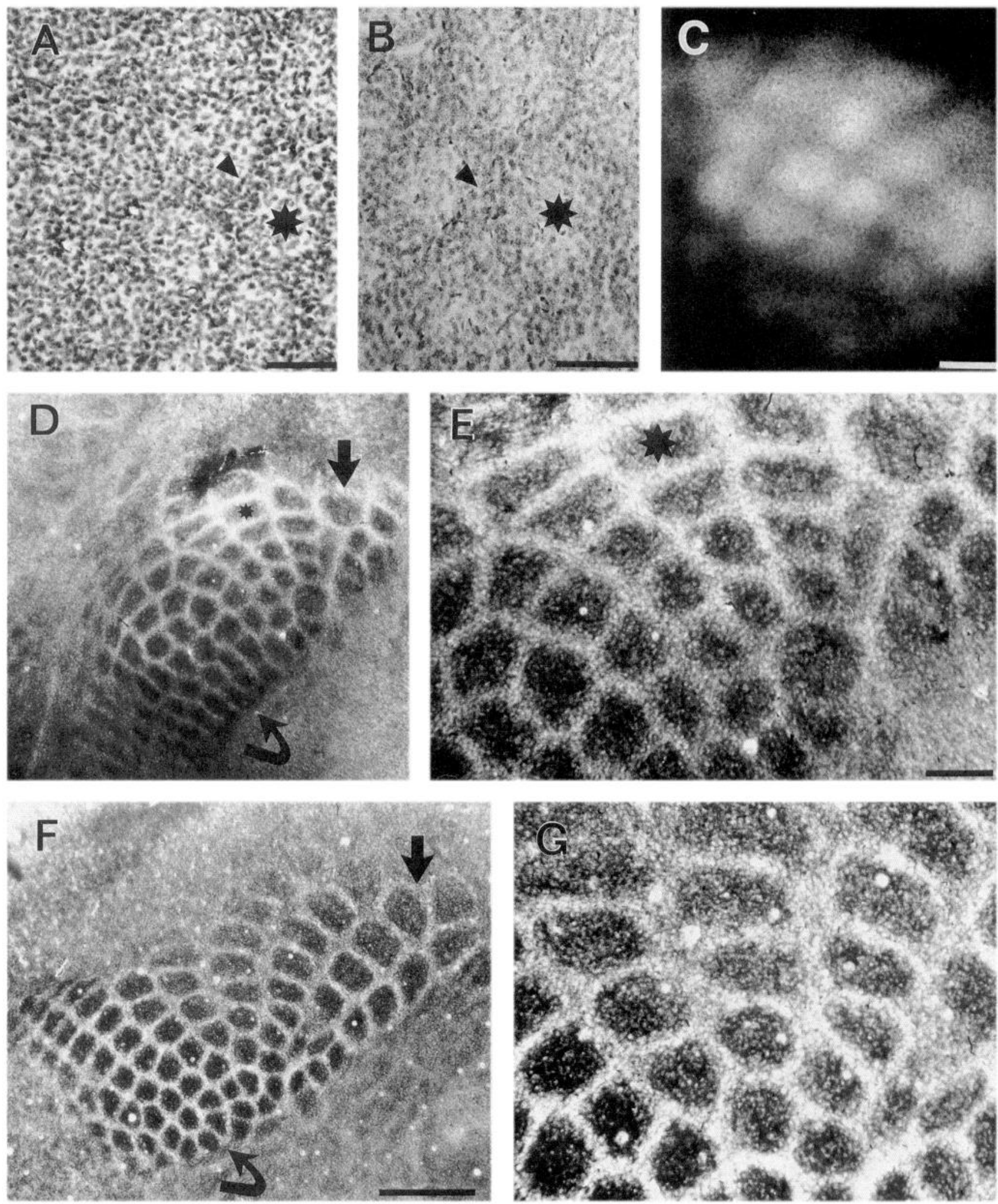

Figure 1. Nissl staining, DiI axonal tracing, and cytochrome oxidase (CO) histochemistry in flattened tangential sections through the postnatal day 7 (P7) normal $(B, D$, and $E)$ and tenascin knockout $(A, C, F$, and $G)$ mouse somatosensory cortex. $A$ and $B$, In the tenascin knockout mouse $(A)$, Nissl-stained barrels are apparent in the smaller barrels of the anterolateral barrel subfield, and resemble normal Nissl-stained barrels again from the anterolateral barrel subfield of a normal P7 mouse (B). Asterisks point out representative barrel hollows, arrowheads point to barrel sides. $C$, DiI fluorescent labeling of thalamocortical axonal projections to barrel hollows (appear as white patches) are normal in the barrel field of a P5 knockout mouse. $D$ and $E$, CO histochemistry in the normal mouse reveals both large and small barrels of the posteromedial (straight arrow) and anterolateral (curved arrow) barrel subfields, with staining (that appears as black patches) that is concentrated in synaptic neuropil of individual barrel hollows (as shown in higher magnification in $E$; asterisk in the same barrel seen in $D$ and $E$ ). Barrel sides and interbarrel septae appear as less-stained (almost white) areas surrounding CO-stained hollows. $F$ and $G, \mathrm{CO}$ staining in the P7 knockout barrel cortex reveals barrel patterns that are indistinguishable from those of the normal mouse. Arrows point out the different barrel subfields as described for $D$. Scale bars: $A-C$, 150 $\mu \mathrm{m} ; E, 150 \mu \mathrm{m}$ for $E$ and $G ; F, 250 \mu \mathrm{m}$ for $F$ and $D$. 

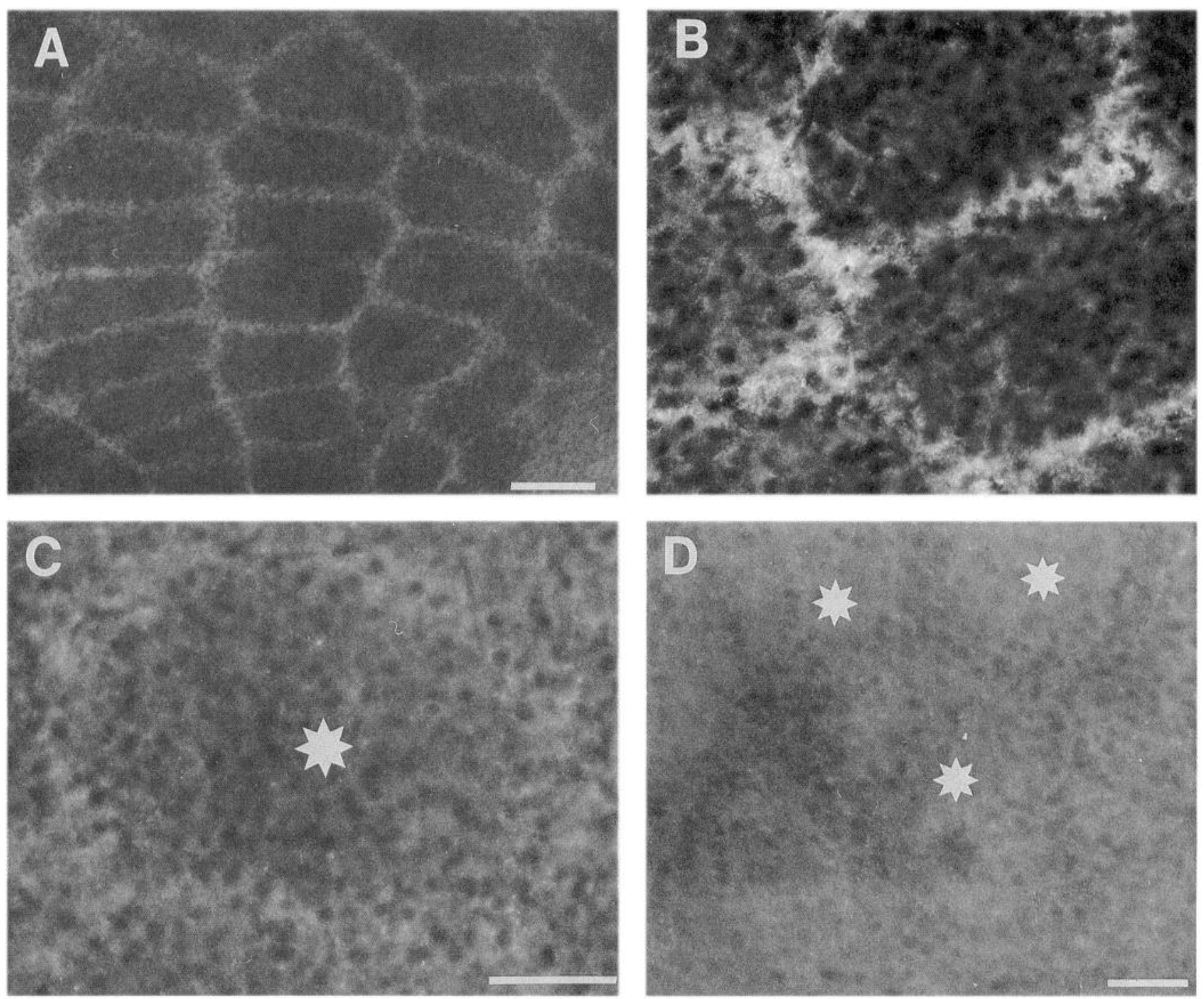

Figure 2. Tenascin immunofluorescence in the barrel field of a P7 normal ( $A$ and $B)$, heterozygous $(C)$, and homozygous tenascin knockout mice (D). A, Tenascin is distributed in boundaries around young barrels, delineating rows $A-D$ (right to left) of the five rows of barrels representing large whiskers (the posteromedial barrel subfield) of the mystacial pad. $B$, Higher magnification of portions of three visible barrels from the same animal shows tenascin is concentrated in barrel boundaries (destined to become interbarrel septae) in the normal P7 mouse barrel field. There is very little tenascin immunostaining in barrel hollows. $C$, A single barrel (asterisk marks the hollow) in the somatosensory cortical barrel field of a heterozygous animal shows an apparent reduction in the tenascin staining in the boundary. $D$, There is no tenascin immunostaining in the barrel field of the P7 tenascin knockout mouse. This micrograph was overexposed to reveal the slight autofluorescence of barrel hollows (asterisks in three), and no staining is present around barrel hollows in the so-called boundaries. Scale bars: $A, 150 \mu \mathrm{m} ; C$ and $D, 50 \mu \mathrm{m}$.

1990). Despite low levels of the tenascin glycoprotein present, e.g., within developing barrel hollows, higher concentrations of the protein within boundaries are quite prominent (Fig. 2B). In heterozygote animals, the barrel field can be clearly discerned using tenascin immunocytochemistry, but the staining is less intense, consistent with a lesser amount of the protein (Fig. 2C). Finally, in homozygote knockout animals, there was a complete lack of tenascin expression (as previously described for these knockouts (Saga et al., 1992). Figure 2D documents the lack of tenascin in barrel boundaries in the P7 knockout barrel field. This photomicrograph was printed as an overexposure to show details of barrels (that possess somewhat autofluorescent barrel hollows) (Senft and Woolsey, 1991) and the lack of tenascin.

\section{The DSD-1-PG proteoglycan in knockout versus normal} barrels

Polyclonal and monoclonal antibodies to the DSD-1-PG proteoglycan (previously referred to as the 473 proteoglycan) (Faissner, 1988) label barrel boundaries in all three genotypes. Figure 3 shows the presence of DSD-1-PG, stained by monoclonal antibody 473HD (Faissner et al., 1994), in barrel boundaries in the P8 (Fig. 3A-C) and P13 (Fig. 3D) barrel field of wild type (Fig. $3 A$ ) and knockout (Fig. $3 B-D$ ) animals. The time course of appearance, and the apparent intensity of immunolabeling of DSD1-PG, appear to be identical in knockout and normal mouse somatosensory cortical barrel boundaries. DSD-1-PG barrel boundaries are present in the second postnatal week (Fig. 3D), 

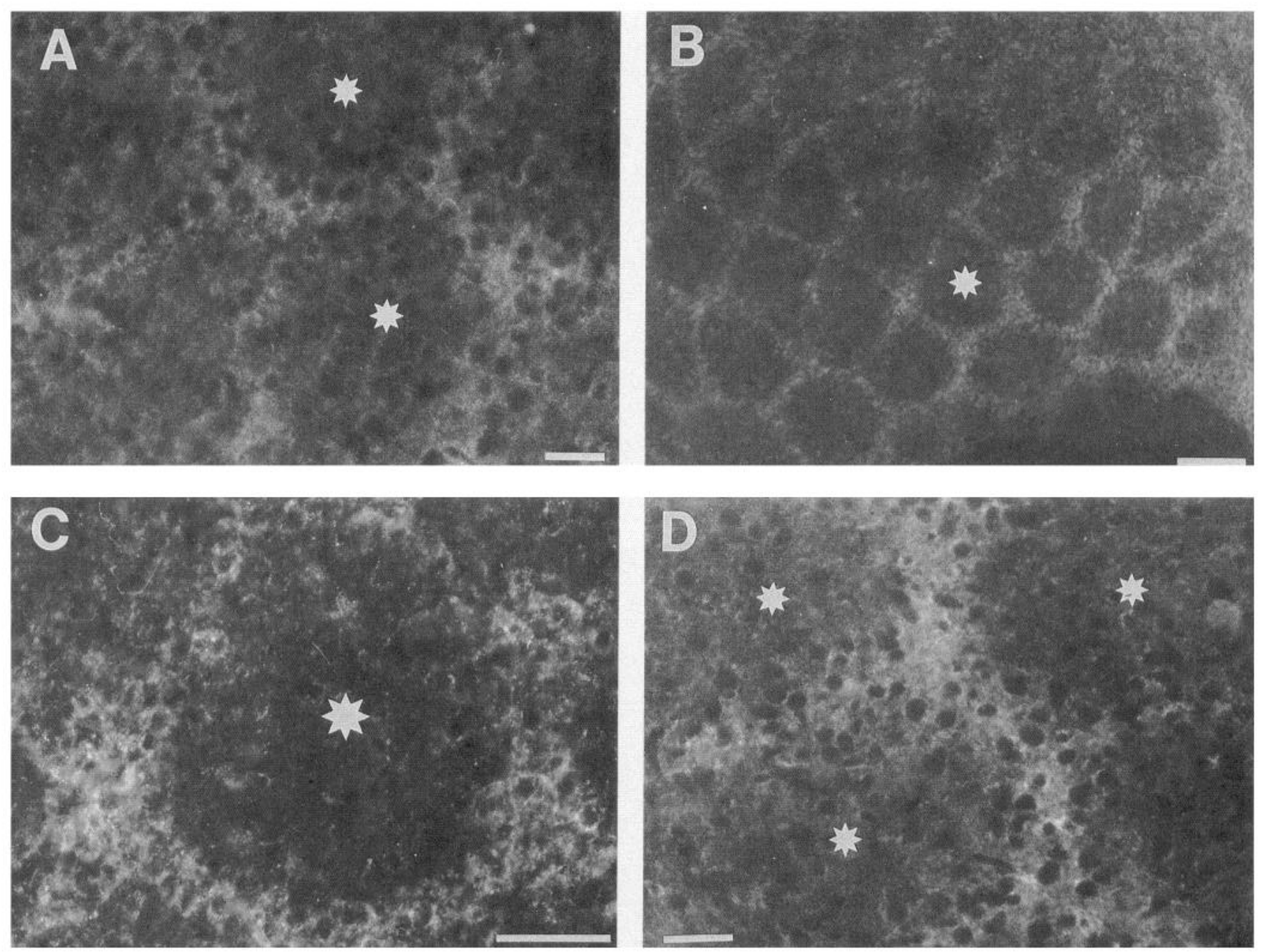

Figure 3. DSD-1-PG proteoglycan immunostaining of barrel boundaries in normal $(A)$ and tenascin-deficient $(B-D)$ mice. DSD-1-PG is found in barrel boundaries in the P8 normal mouse $(A)$ barrel cortex (asterisk marks the hollows of two representative barrels), and the proteoglycan is also in barrel boundaries in the P8 tenascin-knockout mouse $(B$ and $C$ ). Asterisk in $B$ marks a single barrel hollow, shown in higher magnification in $C$. $D$, By P13, DSD-1-PG is still present in barrel boundaries in the knockout (as well as in normal animals, not shown). Scale bars: $A$, $C$, and $D$, $50 \mu \mathrm{m} ; B, 150 \mu \mathrm{m}$.

as is tenascin in low levels in normal animals (Steindler et al., 1989a,b, 1990).

\section{PNA cytochemical labeling of barrels}

Lectin cytochemistry of glycoconjugates is a proven method for studying the presence of glycosylated molecules in a variety of tissues (Wood and McLaughlin, 1976). Our earliest studies of developmental boundaries in the CNS, especially in the emerging barrel field, used this method to stain transient glycoconjugate boundaries (Cooper and Steindler, 1986a). It was possible that PNA could bind to tenascin, although it was our belief (Steindler et al., 1990) that PNA may bind to other glycoproteins and proteoglycans that colocalize with tenascin in brain boundaries.

If tenascin were not the major PNA lectin-binding glycoprotein in the barrel boundaries, and if the arrangement of the other glycoproteins in the boundaries did not require tenascin, we would expect the staining of the barrel fields to be the same in the tenascin knockout and wild-type mice. This is apparently the case for PNA staining, as shown in Figure $4 A-C$. We have not been able to discern obvious differences in lectin binding of glycoconjugates in heterozygote versus normal wild-type animals, as we have for example using tenascin immunocytochemistry (e.g., Fig. 2), perhaps as a result of the binding of a variety of glycoconjugates by this lectin in both genotypes.

The tenascin- $R$ glycoprotein in normal versus tenascin knockout barrel cortex

Immunocytochemistry for the tenascin- $\mathrm{R}$ glycoprotein in all three genotypes reveals a complete lack of barrel boundary labeling. Figure $4, D$ and $E$, shows immunofluorescence for tenascin-R in the $\mathrm{P} 7$ normal $(D)$ and tenascin knockout $(E)$ barrel field. For the most part, there is little tenascin- $\mathrm{R}$ immunoreactivity in the cortical gray matter, and barrels are only recognizable due to the apparent autofluorescent nature of barrel hollows (as previously described (Senft and Woolsey, 1991) (asterisk in Fig. $4 D, E$ ). There is some punctate labeling within and around barrels in the normal and knockout mouse, and subcortical white matter is labeled in a similar fashion in both genotypes (inset, Fig. 4D), but there is no tenascin-R labeling of 

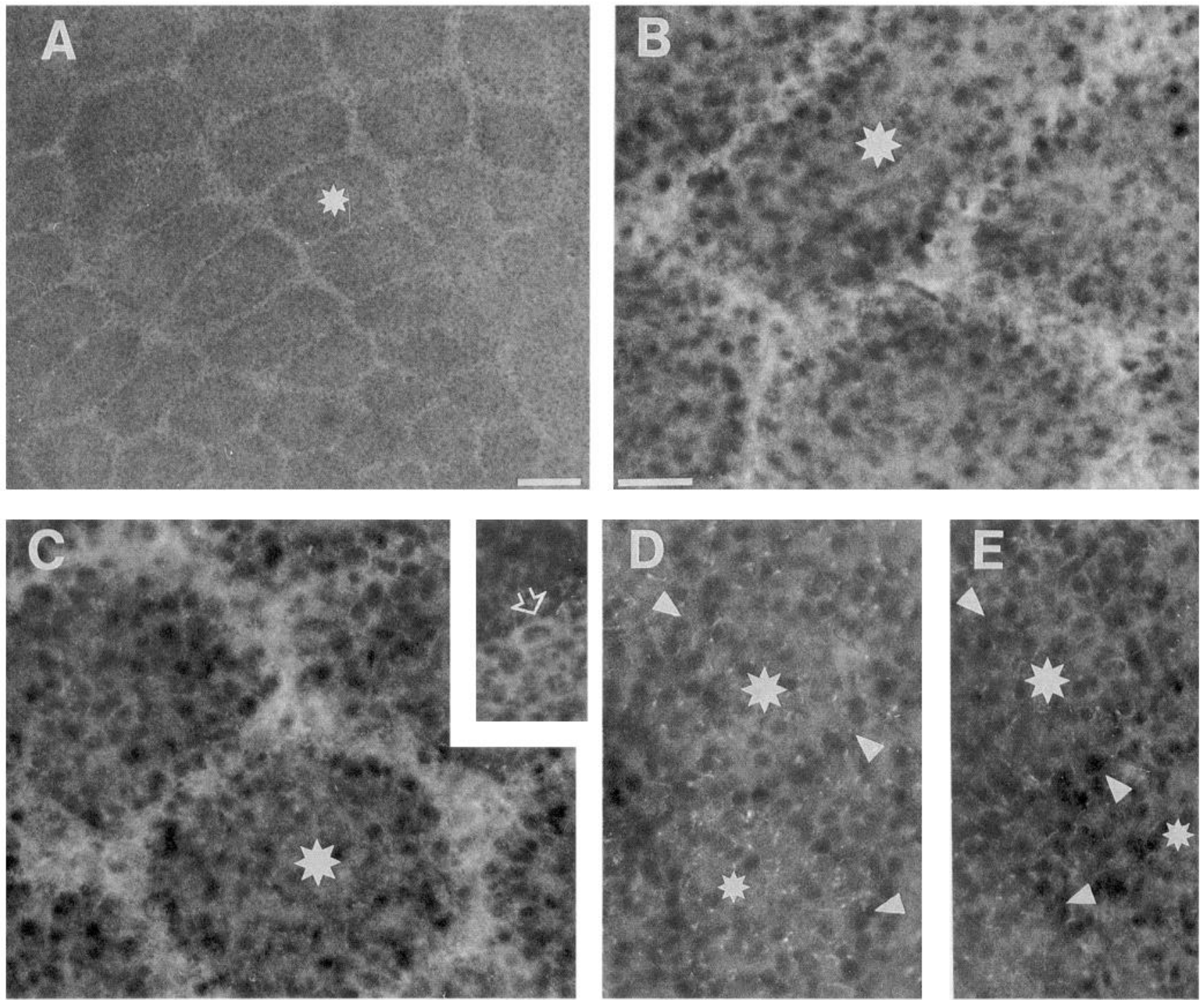

Figure 4. PNA lectin cytochemistry (fluorescence), and tenascin-R immunofluorescence in the P7 barrel field of heterozygous ( $A$ and $B$ ) and homozygous $(C)$ tenascin knockout mice. $A$ and $B$, In heterozygote (and wild-type, with labeling identical to the heterozygote, not shown) animals, PNA-bound glycoconjugates reveal barrel boundaries around individual barrels representing, in this case $(A)$ all five rows of large whisker barrels Asterisks in $A$ and $B$ in representative hollows. $C$, PNA labeling in the tenascin knockout barrel field is indistinguishable from that seen in the heterozygote and wild-type fields. Asterisk in a single barrel hollow. $D$ and $E$, Tenascin-R immunocytochemistry reveals no labeling of barrel boundaries in the normal $(D)$ or tenascin knockout $(E)$ barrel field. Asterisk in representative barrel hollows, arrowheads point to boundaries (interbarrel septae). There is light, autofluorescence of barrel hollows. Inset between $C$ and $D$ shows positive tenascin-R immunoreactivity in the subcortical white matter in the tenascin knockout (which is identical to that seen in the normal animal, not shown), with the arrow pointing to the junction of cortical gray and white matter. Scale bars: $A, 150 \mu \mathrm{m} ; B, 50 \mu \mathrm{m}$ for $B-E$.

boundaries to support a notion that the expression of this molecule is upregulated in response to the deletion of the tenascin-C gene.

\section{Glial scarring in the postnatal tenascin knockout and normal mouse cortex}

Because tenascin is prominently expressed in response to brain injury (Laywell et al., 1992), we initiated a study comparing glial scar formation in normal and tenascin knockout mice. Since the formation of the astroglial scar is a hallmark of brain injury (Cajal, 1928; Clemente, 1958; Reier et al., 1983; Eng, 1988; Reier and Houle, 1988), and it is somewhat controversial as to whether or not any or all of the scar components are expressed in the very young brain following injury (Berry et al., 1983;
Woodward et al., 1993), we will focus on the P13 lesion cases (P10 lesion, $3 \mathrm{~d}$ survival) where previous studies indicated the presence of astrogliosis following this type of injury in the second postnatal week (Balasingam et al., 1994). Figure 5 shows the somatosensory cortex of P13 mice $3 \mathrm{~d}$ after a stab wound at P10. Figure 5, $A$ and $B$, shows a typical GFAP astrocytosis in response to a stab injury of the normal cerebral cortex. Reactive GFAP+ astrocytes surround the site of penetration, and their numbers drop off away from the primary site of injury. Thus, GFAP staining of astrocytes is most concentrated at the site of injury, and a subset of these, immediately surrounding the wound, stain for the DSD-1-PG (Fig. 5C). There were no prominent differences in the pattern of GFAP reactive astrocytes nor the DSD-1-PG staining between normal (Fig. $5 A-C$ ) and 

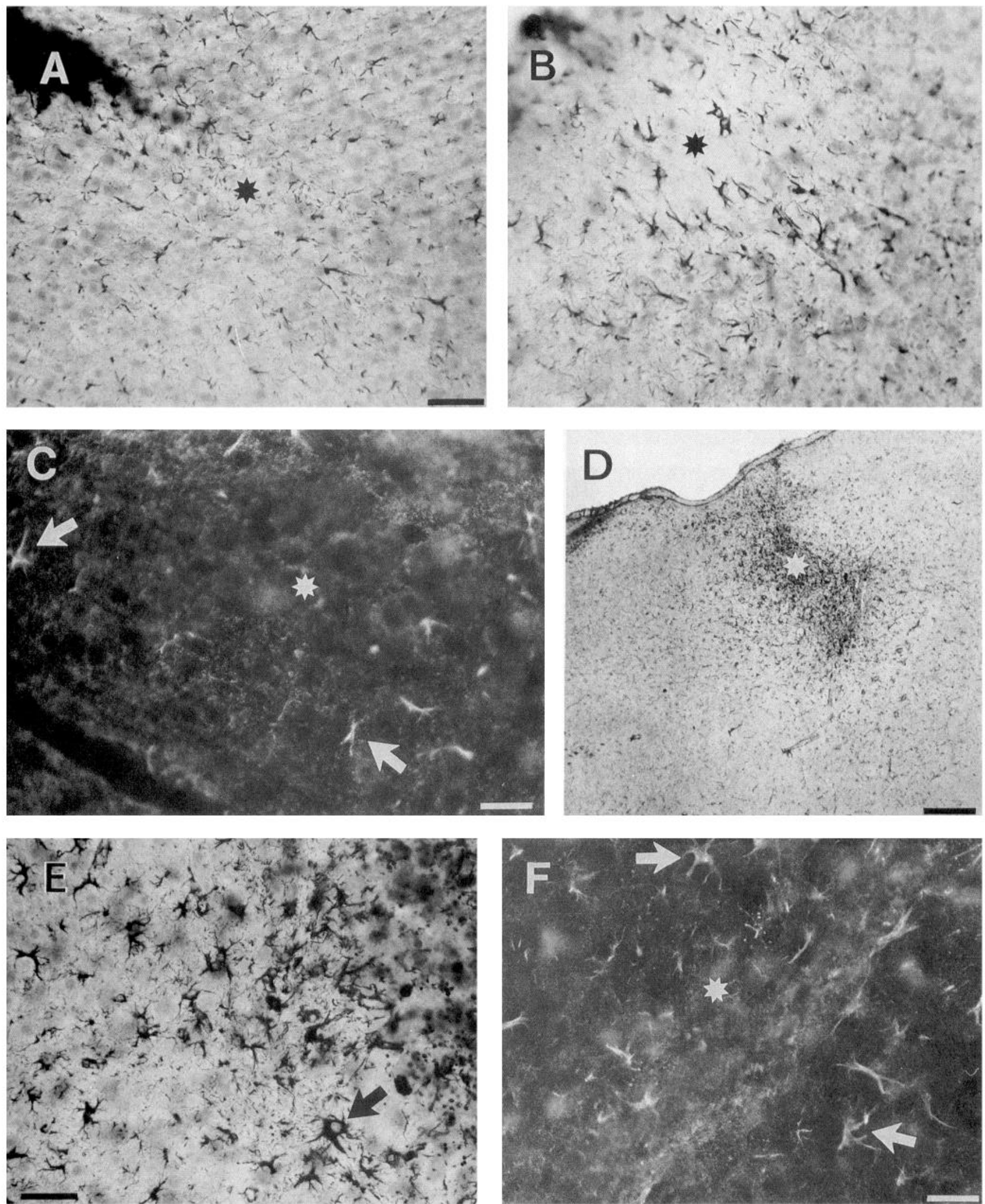

Figure 5. Stab wounds in the P13 normal wild type $(A-C)$ and tenascin knockout $(D-F)$ mouse cerebral cortex, glial fibrillary acidic protein (GFAP, a major intermediate filament protein of astrocytes), and DSD-1-PG proteoglycan immunocytochemistry. Asterisks mark the center of the lesions. $A$ and $B$, In the normal mouse, GFAP labels reactive astrocytes associated with the wound site (appear as black cells), with individual reactive astrocytes being visible near the primary lesion site, and dropping off away from the wound. $C$, Immunofluorescence for the DSD-1-PG proteoglycan in the same case reveals astrocytes (white) in and around the primary wound site (e.g., arrows). $D$ and $E$, GFAP reactive astrocytes associated with a stab wound in the cortex of a tenascin knockout mouse. As in the normal animal, large, swollen (e.g., arrow in E) reactive astrocytes surround the primary lesion site. $F$, As in the normal mouse, DSD-1-PG immunoreactive astrocytes (white cells, e.g., arrows) are also associated with the wound in tenascin knockout mice. Scale bars: $A-C$ and $F, 50 \mu \mathrm{m} ; D, 250 \mu \mathrm{m}$. 
tenascin knockout (Fig. 5D-F) mice, with the possible exception that more labeled astrocytes may be associated with wounds in the Pl3 knockout (e.g., compare Fig. $5 B, E, C, F$ ).

\section{Discussion}

The landmark article of Saga et al. (1992) surprised scientists studying tenascin and the ECM by reporting no obvious defect in devclopment in the absence of tenascin, in spite of the fact that tenascin is one of the most abundant ECM proteins in the developing nervous system, and is prominently expressed in a number of other tissues (for review, see Faissner et al., 1988; Erickson and Bourdon, 1989). A comparable surprise was seen in the more recent knockout of the neural cell adhesion molecule (NCAM) (Tomasiewicz et al., 1993; Cremer et al., 1994), one of the most abundant cell surface proteins in brain and other tissues. In the case of NCAM, however, although the mice appeared grossly normal, defects were noted by those investigators at the histological level. Most obvious was a substantially reduced size of the olfactory bulb, probably due to a defect in migration of granule cells. More subtle changes were observed in one lobule of the cerebellum and some specific cellular distributions. Subtle defects in the tenascin knockout mice may have been missed in the original study by Saga et al. The precise temporal and spatial localization of tenascin in the barrel field boundaries offered an opportunity to look for subtle defects at several levels.

The absence of tenascin could, in principle, have both structural and functional consequences for a barrel field. The battery of markers studied here strongly suggests that barrels are normal in tenascin knockout mice and, hence, the loss of a prominent barrel boundary molecule has not apparcntly affected the normal development of these unique structures. However, we have concentrated on a limited time frame in barrel morphogenesis (P5P13) where the most dramatic aspects of barrel development take place. It is possible, though unlikely, that other aspects of development that occur before this (including part of the critical period where peripheral whisker lesions result in corresponding changes in barrel and barrel boundary morphology (Cooper and Steindler, 1989; Steindler et al., 1990; Woolsey, 1990), as well as maturation of barrel circuitry that continues into adulthood, could be altered in the mutant and should be studied. Nonetheless, based on all previous studies of normal and abnormal development of barrels, if barrel organization is somehow altered by genetic (e.g., in neurologically mutant mice, O'Brien et al., 1987 ) or other factors, it is certainly manifested and visible in the first to second postnatal weeks. If tenascin were an essential structural component, it is also possible that other barrel-associated glycoconjugates would be absent or disorganized in the absence of tenascin. This is apparently not the case, since lectinbound glycoconjugates and the DSD-1-PG proteoglycan appear to contribute to perfectly normal barrel boundaries in its absence. If the barrel boundaries are formed by self-assembly of component proteins, the present study suggests that tenascin may not be a part of the essential framework. It may be added later, after the framework has been assembled. However, there are well-recognized limitations with studying gene knockouts, and, thus, all of these interpretations must be considered in light of the findings that many of the knockout animals generated to date have either no obvious phenotype, subtle malformations, or abnormalities in development and behavior that could result from defective cell and molecular interactions that are secondary to the gene deletion. One knockout mouse, however, has led to malformations in whisker-related barrels. A mutant mouse that lacks functional $N$-methyl-D-aspartate (NMDA) receptors, the NMDAR1 knockout, has recently been shown to lack normal barrel-like patterning in the brainstem trigeminal nuclei ( $\mathrm{Li}$ et al., 1994). The tenascin knockout mouse, thus, provides some insights into the possible role of this molecule during barrel pattern formation, but other approaches must be considered that not only block the actions of this molccule at different times during development, but that also augment the actions of this molecule. Recent studies on the role of nerve growth factor (NGF) during barrel development (Henderson et al., 1994) have shown that injections of antibodies to NGF or an NGF receptor during development do not alter barrel pattern formation despite reductions in the numbers of trigeminal ganglion cells, while injections of excess amounts of NGF rescue more ganglion cells and lead to abnormal whisker-related patterns. Tenascin augmentation paradigms may, likewise, divulge distinct functions of this molecule during pattern formation.

Thalamocortical axons from the thalamic ventrobasal "barreloid" complex (Welt and Steindler, 1977; Dawson and Killackey, 1985; Woolsey, 1990), and cytochrome oxidase patterns (Wong-Riley and Welt, 1980) seem to be organized in normal barrel patterns in tenascin knockout mice. One hypothesis on the function of the boundaries is that they serve as cordones, restricting neuronal processes to the interior of each barrel (Steindler et al., 1989b, 1990; O'Brien et al., 1992; Steindler, 1993). Because of its reputed anti-adhesive activity (Chiquet-Ehrismann, 1991; Taylor et al., 1993; Faissner and Schachner, 1994), tenascin has been a prime candidate for a role in blocking the growth and movement of neurites. While we have not yet looked in detail at individual ccllular proccsses, it is clear that the clustering of large numbers of processes (stained with $\mathrm{CO}$ and DiI) in the centers of barrels, and their relative absence from the boundaries, is apparently normal in the tenascin knockout mice. Thus, if the boundaries do serve as cordones, tenascin does not seem to play an essential role in inhibiting cells and processes from crossing them.

The present study has determined that the DSD-1-PG proteoglycan seems to be expressed, and in functional patterns, independent of tenascin expression. Even though the cytotactin-binding proteoglycan, which appears to colocalize with tenascin/ cytotactin and, hence, also delineates developing barrels, has been hypothesized to be a neuronal ligand for tenascin (Hoffman and Edelman, 1987; Hoffman et al., 1988; Crossin et al., 1989, 1990), studies to date on the DSD-1-PG indicate that it may be expressed by immature glial cells (Gates et al., 1993; Faissner et al., 1994). Tenascin is expressed primarily by astrocytes in the CNS (Bartsch et al., 1992; Laywell et al., 1992), and it seems that these cells might be able to express a variety of boundary molecules that may constitute "backups" when the expression of any one molecule is altered. This could include a variety of chondroitin-, keratan-, and heparin sulfate-containing proteoglycans that have been identified in the developing as well as mature brain (Aquino et al., 1984; Mansour et al., 1990; Snow et al., 1990; Cole and McCabe, 1991; Sheppard et al., 1991; Iwata and Carlson, 1993; Bicknese et al., 1994; Grumet et al., 1994), some of which have been localized in boundaries (Snow et al., 1990; Geisert and Bidanset, 1993). It is possible that boundary molecules act synergistically, with individual molecules involved in particular morphogenetic events (e.g., dendritic patterning) and minor involvement in others (e.g., cell binding/attachment), as has been proposed in studies of these molecules 
in in vitro bioassays (Crossin et al., 1990; Faissner and Kruse, 1990; Lochter et al., 1991; Husmann et al., 1992; Prieto et al., 1992; Faissner and Schachner, 1994). The notion of backup molecules is hypothetical, and recent reviews by one of the authors (HPE) extensively address this issue (including the notion that tenascin "cannot be totally redundant . . . a protein must have a unique function in at least some tissue, or it would revert to a pseudogene ... [even though] a gene can be fixed in a population if it confers only a $1 \%$ survival advantage" (Erickson, 1993). It has also been proposed that other members of the tenascin family, tenascin-R (restrictin (Rathjen et al., 1991)) and tenascin- $X$ might also assume some of the functions of tenascin-C in the knockout brain (Saga et al., 1992; Erickson, 1993, 1994). Studies presented here, that looked at the potentially altered expression of tenascin- $R$ in the barrel cortex of the tenascin knockout, showed that this glycoprotein was not expressed in barrel boundaries in the knockout or normal animals; in fact, there was little or no tenascin- $\mathrm{R}$ expression in the cortices at all except for in white matter. This is in keeping with its predominant expression by oligodendrocytes later in postnatal development and in the adult (Pesheva et al., 1989; Morganti et al., 1990; Steindler et al., 1990; Fuss et al., 1993). Tenascin-X also does not appear to be upregulated in the brain, lung, or thymus of tenascin knockout mice (Saga et al., 1992).

We need to consider the possibility that the boundaries are not the primary functional unit of the barrel, but are a secondary result of functional activity in the center of the barrel. Evidence consistent with this has been presented in previous studies. Jhaveri et al. (1991) reported that thalamocortical axons form a periphery-related pattern before such an organization is detectable in the distribution of ECM molccules. Furthermore, a patterned distribution of ECM molecules appears to result from the downregulation (apparent loss of protein) of these molecules from barrel centers (hollows) in a vibrissae-related pattern; this seems to be a hollowing-out process since ECM molecules such as tenascin are densely expressed in a rather homogeneous fashion at earlier times of cortical development (e.g., E17-P3, Steindler et al., 1989b, 1990; Laywell and Steindler, 1991; Steindler, 1993). In a recent study comparing protein and mRNA, Mitrovic et al. (1994) report no accumulation of tenascin mRNA in the barrel boundaries, where it would be expected if it were being deposited preferentially there. Rather, tenascin mRNA was uniformly distributed within each layer, and was downregulated continuously after birth. Tenascin mRNA disappeared first from layer 4 , being very reduced at $\mathrm{P} 6$, and virtually gone by $\mathrm{P} 9$. Coronal sections showed tenascin protein substantially removed from layer 4 from P3 to P6, and tangential sections showed the residual tenascin to be concentrated in barrel boundaries at P6 (with some remaining at P9). Tenascin protein was completely gone by P15, as observed in previous studies (Steindler et al., 1989a, 1990).

Molecules such as tenascin might not be preferentially deposited in the barrel boundaries, but they may be concentrated there because they are removed preferentially from the barrel centers. Removal of tenascin and other glycoproteins is likely due to the activity of proteases and/or metalloproteases, which, based on studies of other neural systems (Pittman, 1985; Patterson, 1988; Pittman et al., 1989; Sheffield et al., 1994), have been hypothesized to be expressed in barrel hollows as axons grow into the field (Steindler et al., 1989b; Brodkey et al., 1993; Steindler, 1993). As ECM is removed from the center of each barrel, it would be left most concentrated in the boundaries. The re- moval of ECM from barrel hollows may allow the compaction of barrel neuron processes there. Eventually, as the protease action spreads, or following the later ingrowth of other afferent systems (e.g., callosal connections that appear to distribute specifically within the boundaries later than the thalamocortical connections which distribute in the hollows, Olavarria et al., 1984; Zhang and Cooper, personal communication), ECM molecules in the boundaries could be eliminated. In this scenario the boundaries are not deposited or assembled as functional cordones, but rather are the last remnants of ECM left by the wave of protease activity and cellular compaction initiated at the centers of barrels. The possible role of tenascin in brain development, for which we still have no evidence, would, therefore, likely be in the earlier stages when it is uniformly distributed. The very striking patterning of tenascin and other glycoproteins in the barrel boundaries could be a secondary effect, rather than a functional cause, of the cellular organization that sets up a barrel field.

The generation of glial scars in the young brain has been a topic of controversy (Smith et al., 1986; Maxwell et al., 1990), but recent studies suggest that there is a reactive astrogliosis in the neonatal mouse brain that, as in the adult, is modulated by particular cytokines (Balasingam et al., 1994). The glial scar as an impediment to neurite regeneration has been extensively studied (e.g., see Clemente, 1958; Reier et al., 1983; Reier and Houle, 1988; Rudge and Silver, 1990). Recent studies have discussed the possibility that the neurite-growth inhibitory molecules (Schwab et al., 1993) expressed at a wound site may also facilitate the wound healing process as they do in the healing of other wounds (e.g., skin), in addition to affecting neurite growth around the wound (Brodkcy ct al., 1993, 1994). The wound site both in normal and tenascin knockout mice contains GFAP-positive reactive astrocytes, with smaller numbers of cells that just surround the lesion expressing the DSD-1-PG proteoglycan. This is similar to the image of reactive astrocytes that have been shown to upregulate tenascin at both the message and protein levels following penetrating injuries of the adult mouse cortex, where a discrete subset of reactive astrocytes just surrounding the primary wound site exhibit this enhanced expression (Laywell et al., 1992). If anything, the preliminary studies suggest a higher number of astrocytes in the tenascin knockout mouse than in the wild type, suggesting that tenascin may play a role in downregulating proliferation of wound-associated astrocytes. This interesting possibility will require a more extensive and quantitative analysis, but is consistent with cell culture experiments in which tenascin was found to inhibit mitogenic activity of certain cell types (e.g., fibroblast cell lines, Crossin, 1991); however, End et al. (1992) found that tenascin is mitogenic for particular fibroblast and epidermal cell lines. If it is found that a lack of tenascin does affect proliferation and perhaps other responses of astrocytes to injury in the knockout brain, it will be important to study the consequences of such altered astrocytic behaviors during wound healing and regeneration.

In conclusion, we would like to propose that the lack of obvious abnormalities in the cerebral cortical whisker barrels in tenascin knockout mice is somewhat counterbalanced by the findings of other boundary molecule depositions in these same sites in these mutants. It is yet to be determined whether or not these molecules assume the function or compensate for the absence of tenascin during development and wound healing. It is, however, possible that the boundary/cordone hypothesis (Steindler et al., 1989b) needs to be reevaluated, and that the persis- 
tence of molecules such as tenascin around forming barrels is merely a consequence of protease or other molecular mechanisms that degrade or downregulate ECM molecules being expressed later in boundaries than in hollows. The boundary hypothesis for barrel development has relied on functional roles for each of the glial-expressed glycoconjugates during pattern formation and stabilization of these structures, based on observations of conspicuous expressions of molecules such as tenascin in barrel boundaries during critical periods in their development. There has been a mandate to determine the significance of these boundaries in the cortical barrel field, based on findings from transplant and other studies that emphasized other elements such as thalamocortical afferents as being the most consequential in shaping barrel patterns (Jhaveri et al., 1991; Schlaggar and O'Leary, 1991; Senft and Woolsey, 1991; O'Leary et al., 1994). There is no question that the tenascin protein is conserved in all vertebrates (e.g., Gulcher et al., 1989; Jones et al., 1989; Spring et al., 1989; Bartsch et al., 1992; Erickson, 1994), as well as perhaps in some invertebrates (e.g., sponge, leech, and moth, Masuda-Nakagawa and Wiedemann, 1992; Humbert-David and Garrone, 1993; Krull et al., 1994), and it is so abundant in developing and remodeling tissues in all of these species. The challenge still remains to find the specific developmental features or adult perturbations, in both normal and knockout animals, that will add to our understanding of the functions of molecules such as tenascin.

\section{References}

Aquino DA, Margolis RU, Margolis RK (1984) Immunocytochemical localization of a chondroitin sulfate proteoglycan in nervous tissue. II. Studies in developing brain. J Cell Biol 99:1130-1139.

Balasingam V, Tejada-Berges T, Wright E, Bouckova R, Yong VW (1994) Reactive astrogliosis in the neonatal mouse brain and its modulation by cytokines. J Neurosci 14:846-856.

Bartsch S, Bartsch U, Dorries U, Faissner A, Weller A, Ekblom P, Shachner M (1992) Expression of tenascin in the developing and adult cerebellar cortex. J Neurosci 12:736-749.

Berry M, Maxwell WL, Logan A, Mathewson A, McConnell P, Ashhurst DE, Thomas GH (1983) Deposition of scar tissue in the central nervous system. Acta Neurochir [Suppl] 32:31-53

Bicknese AR, Sheppard AM, O'Leary DDM, Pearlman AL (1994) Thalarnocortical axons extend along a chondroitin sulfate proteoglycan-enriched pathway coincident with the neocortical subplate and distinct from the efferent path. J Neurosci 14:3500-3510.

Bignami A, Dahl D (1976) The astroglial response to stabbing: immunofluorescence studies with antibodies to astrocyte-specific protein (GFA) in mammalian and submammalian vertebrates. Neuropathol Appl Neurobiol 2:99-110.

Bixby JL, Harris WA (1991) Molecular mechanisms of axon growth and guidance. Annu Rev Cell Biol 7:117-159.

Brodkey JA, Gates MA, Laywell ED, Steindler DA (1993) The complex nature of interactive neuroregeneration-related molecules. Exp Neurol 123:251-270.

Brodkey JA, Laywell ED, O'Brien TF, Faissner A, Stefannson K, Dorries U, Schachner M, Steindler DA (1994) Focal brain injury results in the upregulation of a developmentally-regulated extracellular matrix protein. J Neurosurg, in press.

Cajal SRY (1928) Degeneration and regeneration of the nervous system. New York: Hafner.

Carroll EW, Wong-Riley M (1984) Quantitative light and electron microscopic analysis of cytochrome oxidase-rich zone in the striate cortex of the squirrel monkey. J Comp Neurol 222:1-17.

Chiquet-Ehrismann R (1991) Anti-adhesive molecules of the extracellular matrix. Curr Opin Cell Biol 3:80-804.

Clemente CD (1958) The regeneration of peripheral nerves inserted into the cerebral cortex and the healing of cerebral lesions. J Comp Neurol 109:123-151.

Cole G, McCabe CF (1991) Identification of a developmentally regu- lated keratan sulfate proteoglycan that inhibits cell adhesion and neurite outgrowth. Neuron 7:1007-1018.

Cooper NGF, Steindler DA (1986a) Lectins demarcate the barrel subfield in the somatosensory cortex of the early postnatal mouse. J Comp Neurol 243:157-168.

Cooper NGF, Steindler DA (1986b) Monoclonal antibody to glial fibrillary acidic protein reveals a parcellation of individual barrels in the early postnatal mouse somatosensory cortex. Brain Res 380:341348 .

Cooper NGF, Steindler DA (1989) Critical period-dependent alterations of the transient body image in the rodent cerebral cortex. Brain Res 489:167-176.

Crandall JE, Misson J-P, Butler D (1990) The development of radial glia and radial dendrites during barrel formation in mouse somatosensory cortex. Dev Brain Res 55:87 94 .

Cremer H, Lange R, Christoph A, Plomann M, Vopper G, Roes J, Brown R, Baldwin S, Kraemer P, Scheff S, Barthels D, Rajewsky K, Wille W (1994) Inactivation of the N-CAM gene in mice results in size reduction of the olfactory bulb and deficits in spatial learning. Nature 367:455-459.

Crossin KL (1991) Cytotactin binding: inhibition of stimulated proliferation and intracellular alkalinization in fibroblasts. Proc Natl Acad Sci USA 88:11403-11407.

Crossin KL, Hoffman S, Grumet M, Thiery JP, Edelman GM (1986) Site-restricted expression of cytotactin during development of the chicken embryo. J Cell Biol 102:1917-1930.

Crossin KL, Hoffman S, Tan S-S, Edelman GM (1989) Cytotactin and its proteoglycan ligand mark structural and functional boundaries in somatosensory cortex of the early postnatal mouse. Dev Biol 136: 381-392.

Crossin KL, Prieto AL, Hoffman S, Jones FS, Freidlander DR (1990) Expression of adhesion molecules and the establishment of boundaries during embryonic and neural development. Exp Neurol 109:618.

Dawson DR, Killackey HP (1985) Distinguishing topography and somatotopy in the thalamocortical projections of the developing rat. Dev Brain Res 17:309-313.

Dickinson WJ (1988) On the architecture of regulatory systems: evolutionary insights and implications. Bioessays 8:204-208.

Edelman GM (1992) Morphoregulation. Dev Dynam 193:2-10.

Edelman GM, Jones FS (1992) Cytotactin: a morphoregulatory molecule and a target for regulation by homeobox gene products. Trends Biol Sci 17:228-232.

End P, Panayotou G, Entwistle A, Waterfield MD, Chiquet M (1992) Tenascin: a modulator of cell growth. Eur J Biochem 209:1041-1051.

Eng LF (1988) In: The biochemical pathology of astrocytes. New York: Liss.

Erickson HP (1993a) Gene knockouts of c-src, transforming growth factor $\beta-1$, and tenascin suggests superfluous, nonfunctional expression of proteins. J Cell Biol 120:1079-1081.

Erickson HP (1993b) Tenascin-C, tenascin- $R$ and tenascin-X: a family of talented proteins in search of functions. Curr Opin Cell Biol 5:869-876.

Erickson HP (1994) Evolution of the tenascin family - implications for function of the C-terminal fibrinogen-like domain. Perspect Dev Neurobiol, in press.

Erickson HP, Bourdon MA (1989) Tenascin: an extracellular matrix protein prominent in specialized embryonic tissues and tumors. Annu Rev Cell Bicl 5:71-92.

Faissner A (1988) Monoclonal antibody identifies a proteoglycan expressed by a subclass of glial cells. Soc Neurosci Abstr 14:920.

Faissner A, Schachner M (1994) Tenascin and janusin-glial recognition molecules involved in neural development and regeneration. In: Neuroglial cells (Kettenmann H, Ransom B, eds). London: Oxford UP.

Faissner A, Kruse J, Chiquet-Ehrismann R, Mackie EJ (1988) The high-molecular-weight $\mathrm{J} 1$ glycorroteins are immunochemically related to tenascin. Differentiation 37:104-114.

Faissner A, Clement A, Lochter A, Streit A, Mandl C, Schachner M (1994) Isolation of a neural chondroitin sulfate proteoglycan with neurite outgrowth promoting properties. J Cell Biol 126:783-799.

Faissner AW, Kruse J (1990) J1/Tenascin is a repulsive substrate for central nervous system neurons. Neuron 5:627-637.

Fuss B, Wintergerst WA, Bartsch U, Schachner M (1993) Molecular characterization and in situ mRNA localization of the neural recog- 
nition molecules $\mathrm{J1}-160 / 180$ : a modular structure similar to tenascin. J Cell Biol 120:1237-1249.

Gates MA, O'Brien TF, Faissner A, Steindler DA (1993) Neuron-glial interactions during the in vivo and in vitro development of the nigrostriatal circuit. J Chem Neuroanat 6:179-189.

Geisert EE, Bidanset DJ (1993) A central nervous system keratan sulfate proteoglycan: localization to boundaries in the neonatal brain. Dev Brain Res 75:163-173.

Godement P, Vaneslow J, Thanos S, Bonhoeffer F (1987) A study in developing visual system using a new method of staining neurons and their processes in fixed tissue. Development 101:697-713.

Grumet M, Milev P, Sakurai T, Karthikeyan L, Bourdon M, Margolis RK, Margolis RU (1994) Interactions with tenascin and differential effects on cell adhesion of neurocan and phosphacan, two major chondroitin sulfate proteoglycans of nervous tissue. J Biol Chem 269: 12142-12146.

Gulcher JR, Nies DE, Marton LS, Stefansson K (1989) An alternatively spliced region of the human hexabrachion contains a repeat of potential N-glycosylation sites. Proc Natl Acad Sci USA 86:1588-1592.

Henderson TA, Johnson EM Jr, Osborne PA, Jacquin MF (1994) Fetal NGF augmentation preserves excess trigeminal ganglion cells and interrupts whisker-related pattern formation. J Neurosci 14:33893403.

Hoffman S, Edelman GM (1987) A proteoglycan with HNK-a antigenic determinants is a neuron-associated ligand for cytotactin. Proc Natl Acad Sci USA 84:2523-2527.

Hoffman S, Crossin KL, Edelman GM (1988) Molecular forms, binding functions, and developmental expression patterns of cytotactin and cytotactin-binding proteoglycan, an interactive pair of extracellular matrix molecules. J Cell Biol 106:519-532.

Honig MG, Hume RI (1986) Fluorescent carbocyanine dyes allow living neurons of identified origin to be studied in long-term cultures. J Cell Biol 103:171-187.

Humbert-David N, Garrone R (1993) A six-armed, tenascin-like protein extracted from the Porifera oscarella tuberculata (Homosclerophorida). Eur J Biochem 216:255-260.

Husmann K, Faissner A, Schachner M (1992) Tenascin promotes cerebellar granule cell migration and neurite outgrowth by different domains in the fibronectin type III repeats. J Cell Biol 116:1475-1486.

Iwata M, Carlson SS (1993) A large chondroitin sulfate proteoglycan has the characteristics of a general extracellular matrix component of adult brain. J Neurosci 13:195-207.

Jacobson M (1991) Developmental neurobiology. New York: Plenum.

Jhaveri S, Erzurumlu RS, Crossin K (1991) Barrel construction in the rodent neocortex: role of thalamic afferents versus extracellular matrix molecules. Proc Natl Acad Sci USA 88:4489-4493.

Jones FS, Hoffman S, Cunningham BA, Edelman GM (1989) Detailed structural model of cytotactin: protein homologies, alternative RNA splicing, and binding regions. Proc Natl Acad Sci USA 86:19051909.

Krull CF, Morton DB, Faissner A, Schachner M, Tolbert LP (1994) Spatiotemporal pattern of expression of tenascin-like molecules in a developing insect olfactory system. J Neurobiol 25:515-534.

Kruse J, Keilhauer G, Faissner A, Timpl R, Schachner M (1985) The $\mathrm{J} 1$ glycoprotein-a novel nervous system cell adhesion molecule of the L2/HNK-1 family. Nature 316:146-148.

Laywell E, Steindler DA (1991) Boundaries and wounds, glia and glycoconjugates: cellular and molecular analyses of developmental partitions and adult brain lesions. Ann NY Acad Sci 633:122-141.

Laywell ED, Dörries U, Bartsch U, Faissner A, Schachner M, Steindler DA (1992) Enhanced expression of the developmentally regulated extracellular matrix molecule tenascin following adult brain injury. Proc Natl Acad Sci USA 89:2634-2638.

Li Y, Erzurumlu RS, Chen C, Jhaveri S, Tonegawa S (1994) Whiskerrelated neuronal patterns fail to develop in the trigeminal brainstem nuclei of NMDAR1 knockout mice. Cell 76:427-437.

Lightner VA, Slemp CA Erickson HP (1990) Localization and quantitation of hexabrachion (tenascin) in skin, embryonic brain, tumors, and plasma. Ann NY Acad Sci 580:260-275.

Lochter A, Vaughan L, Kaplony A, Prochiantz A, Schachner M. Faissner A (1991) Jl/tenascin in substrate-bound and soluble form displays contrary effects on neurite outgrowth. J Cell Biol 113:11591171.

Mansour H, Asher R, Dahl D, Labkovsky B, Perides F, Bignami A (1990) Permissive and non-permissive reactive astrocytes: immuno- fluorescence study with antibodies to the glial hyaluronate-hinding protein. J Neurosci Res 25:300-311.

Masuda-Nakagawa LM, Wiedemann C (1992) The role of matrix molecules in regeneration of Leech CNS. J Neurobiol 23:551 567.

Matsumoto K, Ishihara N, Inoko AA, Ikemura T (1992) Extracellular matrix protein tenascin-like gene found in human MHC class III region. Immunogentelics 36:400-403

Maxwell WL, Follows R, Ashhurst DE, Berry M (1990) The response of the cerebral hemisphere of the rat to injury. II. The neonatal rat. Philos Trans R Soc Lond [Biol] 328:501-513.

McCandlish CA, Waters RS, Cooper NGF (1989) Early development of the representation of the body surface in SI cortex barrel field in neonatal rats as demonstrated with peanut agglutinin binding: evidence for differential development within the rattunculus. Exp Brain Res 77:425-431.

McKeon RJ, Schreiber J, Rudge S, Silver J (1991) Reduction of neurite outgrowth in a model of glial scarring following CNS injury is correlated with the expression of inhibitory molecules on reactive astrocytes. J Neurosci 11:3398-3411.

Mitrovic N, Dorries U, Schachner M (1994) Expression of the extracellular matrix glycoprotein tenascin in the somatosensory cortex of the mouse during postnatal development: an immunocytochemical and in situ hybridization analysis. J Neurocytol 23:364-378.

Morganti CM, Taylor J, Pesheva P, Schachner M (1990) Oligodendrocyte-derived J1-160/180 extracellular matrix proteins are adhesive or repulsive depending on the partner cell type and time of interaction. Exp Neurol 109:98-110.

O'Brien TF, Steindler DA, Cooper NGF (1987) Abnormal glial and glycoconjugate dispositions in the somatosensory cortical barrel field of the early postnatal reeler mutant mouse. Dev Brain Res 32:309 317.

O'Brien TF, Faissner A, Schachner M, Steindler DA (1992) Afferentboundary interactions in the developing neostriatal mosaic. Dev Brain Res 65:259-267.

Olavarria J, Van Sluyers RC, Killackey HP (1984) Evidence for the complementary organization of callosal and thalamic connections within rat somatosensory cortex. Brain Res 291:364-368.

O'Leary DDM (1989) Do cortical areas emerge form a protocortex? Trends Neurosci 12:400-406.

O'Leary DDM, Schlaggar BL, Stanfield BB (1992) The specification of sensory cortex: lessons from cortical transplantation. Exp Neurol 115:121-126.

O'Leary DDM, Schlaggar BL, Tuttle R (1994) Specification of neocortical areas and thalamocortical connections. Annu Rev Neurosci $17: 419-439$.

Patterson $\mathrm{PH}$ (1988) On the importance of being inhibited, or saying no to growth cones. Neuron 1:263-267.

Pesheva P, Spiess E, Schachner M (1989) J1-160 and J1-180 are oligodendrocyte-secreted nonpermissive substrates for cell adhesion. $\mathrm{J}$ Cell Biol 109:1765-1778.

Pittman RN (1985) Release of plasminngen activator and a calcium dependent metalloprotease from cultured sympathetic and sensory neurons. Dev Biol 110:91-101.

Pittman RN, Ivins JK, Buettler HM (1989) Neuronal plasminogen activators: cell surface binding sites and involvement in neurite outgrowth. J Neurosci 9:4269-4286.

Prieto AL, Andersson-Fisone C, Crossin KL (1992) Characterization of multiple adhesive and counteradhesive domains in the extracellular matrix protein cytotactin. J Cell Biol 119:663-678.

Rathjen FG, Wolff JM, Chiquet-Ehrismann R (1991) Restrictin: a chick neural extracellular matrix protein involved in cell attachment copurifies with the cell recognition molecule F11. Development 113: 151-164.

Reier PJ, Houle JD (1988) The glial scar: its bearing on axonal regeneration and transplantation approaches to CNS repair. New York: Raven.

Reier PJ, Stensaas LJ, Guth L (1983) The astrocytic scar as an impediment to regeneration in the central nervous system. New York: Raven.

Rettig WJ, Hoffman S, Su SL, Garin-Chesa P (1992) Species diversity of neuronectin and cytotactin expression patterns in the vertebrate central nervous system. Brain Res 590:219-228.

Rhoades RW, Bennett-Clarke CA, Chiaia NL, White FA, MacDonald GJ, Haring GJ, Jacquin MJ (1990) Development and lesion-induced reorganization of the cortical representation of the rat's body surface 
as revealed by immunocytochemistry for serotonin. J Comp Neurol 293:190-207.

Rudge JS, Silver J (1990) Inhibition of neurite outgrowth on astroglial scars in vitro. J Neurosci 10:3594-3603.

Saga Y, Yagi T, Ikawa Y, Sakakura T, Aizawa S (1992) Mice develop normally without tenascin. Genes Dev 6:1821-1831.

Sanes JR (1989) Extracellular matrix molecules that influence neural development. Annu Rev Neurosci 12:491-516.

Schlaggar BL, O'Leary DDM (1991) Potential of visual cortex to develop an array of functional units unique to somatosensory cortex. Science 252:1556-1560.

Schwab ME, Kapfhammer JP, Bandtlow CE (1993) Inhibitors of neurite growth. Annu Rev Neurosci 16:565-595.

Senft SL, Woolsey TA (1991) Growth of thalamic afferents into mouse barrel cortex. Cereb Cortex 1:308-335.

Sheffield JB, Krasnopolsky V, Dehlinger E (1994) Inhibition of retinal growth cone activity by specific metalloproteinase inhibitors in vitro. Dev Dynam 200:79-88.

Sheppard A M, Hamilton SK, Pearlman AL (1991) Changes in the distribution of extracellular matrix components accompany early morphogenetic events of mammalian cortical development. J Neurosci 11:3928-3942.

Smith GM, Silver J (1986) Changing role of forebrain astrocytes during development, regenerative failure, and induced regeneration upon transplantation. J Comp Neurol 251:23-43.

Snow DM, Steindler DA, Silver J (1990b) Molecular and cellular characterization of the glial roof plate of the spinal cord and optic tectum: a possible role for a proteoglycan in the development of an axon barrier. Dev' Biol 138:359-376.

Spring J, Beck K, Chiquet-Ehrismann R (1989) Two contrary functions of tenascin: dissection of the active site by recombinant tenascin fragments. Cell 59:325-334.

Steindler DA (1993) Glial boundaries in the developing nervous system. Annu Rev Neurosci 16:445-470.

Steindler DA, Cooper NGF (1987) Glial and glycoconjugate boundaries during postnatal development of the central nervous system. Dev Brain Res 36:27-38.

Steindler DA, O'Brien TF, Cooper NGF (1988) Glycoconjugate bound- aries during early postnatal development of the neostriatal mosaic. J Comp Neurol 267:357-369.

Steindler DA, Cooper NGF, Faissner A, Schachner M (1989a) Boundaries defined by adhesion molecules during development of the cerebral cortex: the J1/tenascin glycoprotein in the mouse somatosensory cortical barrel field. Dev Biol 131:243-260.

Steindler DA, Faissner A, Schachner M (1989b) Brain "cordones": glial and adhesion molecule-transient boundaries define developing functional units. Commun Dev Neurobiol 1:29-60.

Steindler DA, $\mathrm{O}^{\prime}$ Brien TF, Laywell E, Harrington K, Faissner A, Schachner M (1990) Boundaries during normal and abnormal brain development: in vivo and in vitro studies of glia and glycoconjugates. Exp Neurol 109:35-56.

Taylor J, Pesheva J, Schachner M (1993) Influence of janusin and tenascin on growth cone behavior in vitro. J Neurosci Res 35:347362.

Tomasiewicz H, Ono K, Yee D, Thompson C, Goridis C, Rutishauser U, Magnuson R (1993) Genetic deletion of a neural cell adhesion molecule variant (N-CAM-180) produces distinct defects in the central nervous system. Neuron 11:1163-1174.

Welt C, Steindler DA (1977) Somatosensory cortical barrels and thalamic barreloids in reeler mutant mice. Neuroscience 2:755-766.

Wong-Riley M (1979) Changes in the visual system of monocularly sutured or enucleated cats demonstrable with cytochrome oxidase histochemistry. Brain Res 171:11-28.

Wong-Riley MTT, Welt C (1980) Histochemical changes in cytochrome oxidase of cortical barrels after vibrissal removal in neonatal and adult mice. Proc Natl Acad Sci USA 77:2333-2337.

Wood JG, McLaughlin BJ (1976) Cytochemical studies of lectin binding sites in smooth membrane cisternae of rat brain. Brain Res 118: $15-26$.

Woodward SK, Treherne JM, Knott GW, Fernandez J, Varga ZM, Nicholls JG (1993) Development of connections by axons growing through injured spinal cord of neonatal opossum in culture. J Exp Biol 176:77-88.

Woolsey TA (1990) Peripheral alteration and sonatosensory development. New York: Wiley.

Woolsey TA, van der Loos H (1970) The structural organization of layer IV in the somatosensory region (SI) of the mouse cerebral cortex: the description of a cortical field composed of discrete cytoarchitectonic units. Brain Res 17:205-242. 